J, I15

\title{
МОТИВАЦІЯ ПЕРСОНАЛУ ЯК ВАЖІЛЬ ПІДВИЩЕННЯ ПРОДУКТИВНОСТІ ПРАЦІ НА ПІДПРИЕМСТВІ
}

Янченко Н. В., канд. екон. наук, доцент

Харківський національний університет будівництва та архітектури

Благой В.В., канд. екон. наук, доцент

Харківський національний університет будівництва та архітектури

Тихомирова А. О., студентка групи ЕП-41 спеціальності «Економіка підприсмства»

Харківський національний університет будівництва та архітектури

Постановка проблеми. На сьогодні державні підприємства не приносять великого прибутку, однією з проблем є не досить гарна мотивація персоналу. Як результат більшість співробітників не любить роботу і намагається працювати заради грошей, співробітників необхідно змушувати виконувати роботу, використовуючи адміністративний, економічний і психологічний тиск. Це актуалізує необхідність дослідження проблем мотивації персоналу.

Аналіз останніх наукових досліджень і публікацій. Науковим базисом мотивації є сучасні теорії мотивації. Для того, щоб провести аналіз треба ознайомитися з теоріями, що стосуються мотивації людини. Це дасть змогу ефективно розкрити поняття. Розглянемо роботи 3 мотиваційних теорій Абрахама Маслоу [1] (1954), Фредрік Герцберг [2, с. 25] (1957) і К. Альдерфера [3, с. 78] (1940) та Д. Мак-Клелланда (1917)[4].

Невирішені складові загальної проблеми. Потребують подальшого розв'язання питання, пов'язані з оптимізацією виробництва, удосконаленням методів мотивації працівників та інше. 
Формулювання цілей статті. Головною метою цієї статті є виявлення нових та вплив на персонал старих методів мотивації, удосконалення, яких може сприяти оптимізації виробництва на підприємстві.

Виклад основного матеріалу дослідження. Згідно 3 ієрархією потреб Авраама Маслоу[1], у людей є внутрішній мотив, який наштовхує їх діяти. Ієрархія починається з найнижчих потреб і піднімається до найвищих потреб. Основні потреби людини відповідно до Маслоу - це фізіологічні потреби, потреби в безпеці, потреба в любові, потреби в повазі та потреби в самореалізації [1]. Задоволення цих потреб дає індивідуальну впевненість у собі та досягнення у роботі. Це дає відчуття вартості, здібності та сили. Потреби, пов'язані з повагою до інших включає потребу в статусі, визнання, вдячності, важливості та престижу. Самореалізація це найвищий рівень потреб, і особам потрібно досягти найкращого самопрояву. Задоволення цієї потреби дає індивідуальне відчуття досягнення.

Теорія мотивації (гігієни) Герцберга [2] більше концентрується на факторах, які ведуть до задоволеності або незадоволення роботою. Гігієнічні фактори описують відносини працівника до середовища, в якому він виконує свою роботу. Це ті елементи в роботі, які сприяють появі негативних почуттів у роботі і не спонукають людей до більшого зусилля[2; с. 25].

Від піраміди Маслоу теорія Альдерфера [3] відрізняється тим, що, згідно 3 нею, існує всього три групи потреб (звідси, до речі, і назва теорії - ERG): existence - потреби існування, до яких відносяться фізіологічні потреби i потреби в безпеці; relatedness - потреби зв'язку, що відображають соціальну природу людини; growth - потреби зростання, до яких належать потреби людини, пов'язані з його прагненням розвиватися і особистісно зростати.

Девід Мак-Клелланд[4] поділяв всі потреби на три великі групи. До них належать потреби у владі, потреби в успіху і потреби в причетності. Один 3 найважливіших висновків теорії Мак-Клелланда зачіпає безпосередньо мотивацію здібностей підприємця в соціумі взагалі. Вчений мав на думці, що соціум 3 переважною мотивацією до досягнень здатний породити велику 
кількість активних, підприємливих і ініціативних підприємців, які, в свою чергу, здатні прискорити зростання економічних показників цього соціуму. Підприємці повинні бути готові брати на себе ризики і ця готовність безпосередньо впливає на потреби до досягнення.

Кожен з авторів пропонує свою класифікацію потреб, що мають найбільший вплив на трудову діяльність людини (див. рисунок 1).

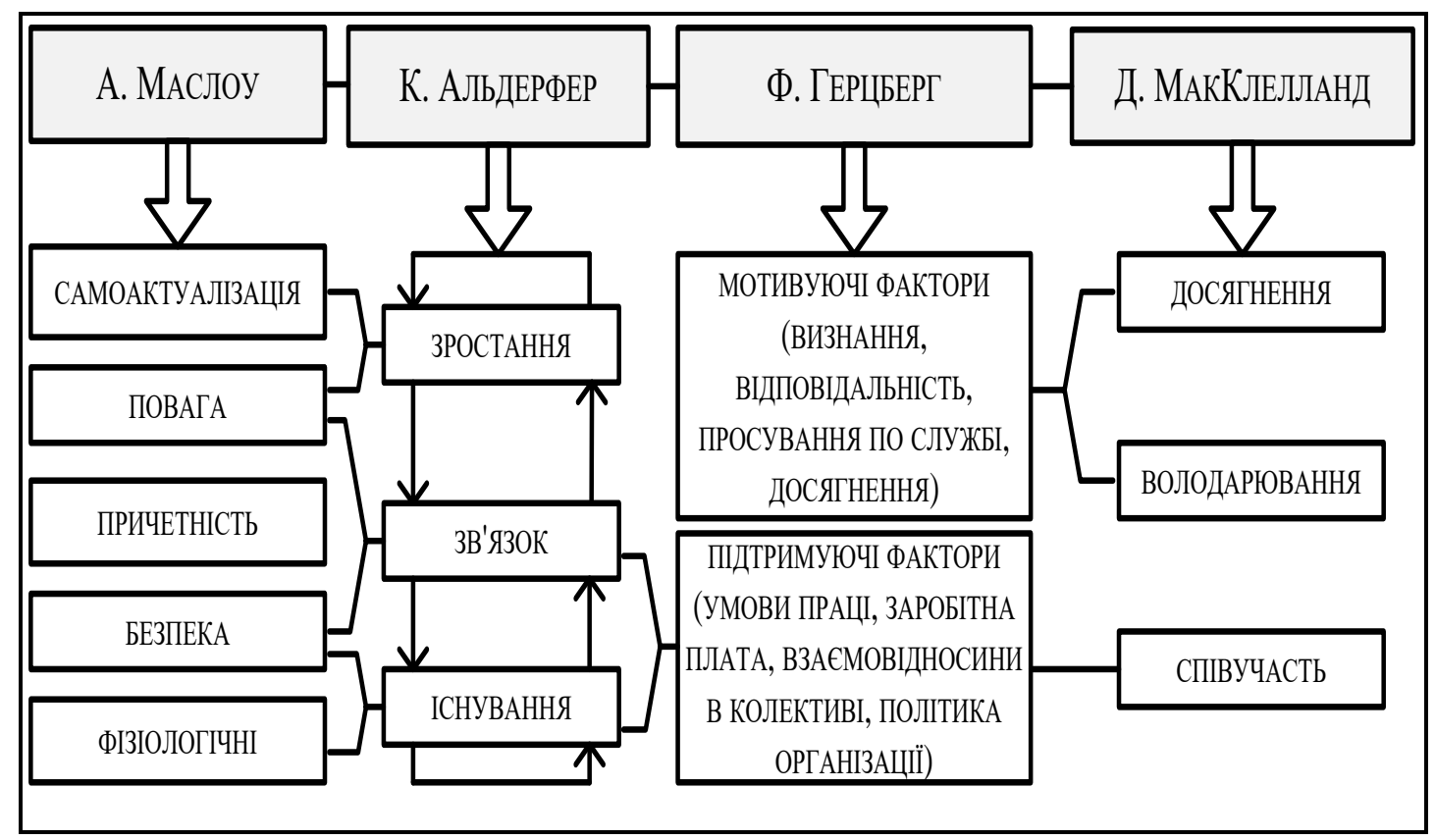

Рис. 1. Співвідношення груп потреб, запропонованих зарубіжними авторами змістовних теорій мотивації

Tеорії $\epsilon$ основою для сприйняття людських мотиваторів. Саме на підприємстві теорії мотивації грунтуються на ідентифікації таких внутрішніх потреб, які примушують людей діяти так, а не інакше. Але, попри значні досягнення відомих вітчизняних та зарубіжних дослідників у даній сфері, необхідно розглянути нові фактори, що будуть впливати на мотивацію.

Вмілий підбір даних мотиваційних важелів, можуть забезпечити високу продуктивність праці, кожного з робітників. На жаль, в Україні, володіючи значним в світі кадровим і інтелектуальним потенціалом, компанії недостатньо використовують інструменти, пов'язані 3 підвищенням мотивації співробітників, роблячи основний акцент на «маніпулюванні зарплатою»: 
підвищуючи або знижуючи в залежності від успіхів структури на ринку. Але часом сучасних менеджерів це не влаштовує: працівник повинен бачити перспективу кар'єрного росту в цій компанії, а якщо ж ні, то як показує практика, такий співробітник буде шукати інше місце роботи.

За допомогою опитування проектом WVS [5], можна з’ясувати, які важелі є головними для мотивації українців (див табл. 1).

Таблиия 1

Опитування українців за проектом WVS

\begin{tabular}{|c|c|c|c|c|c|c|c|}
\hline \multirow[b]{2}{*}{ 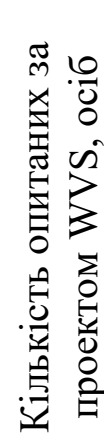 } & \multirow[b]{2}{*}{ Питання (від V70 до V79) } & \multicolumn{6}{|c|}{ Варіанти відповідей (у відсотках): } \\
\hline & & 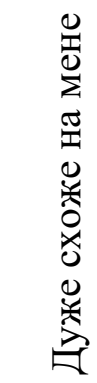 & 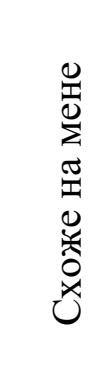 & 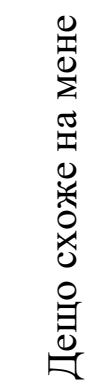 & 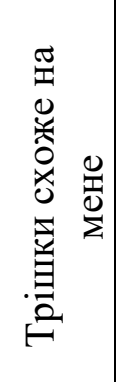 & 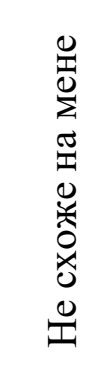 & 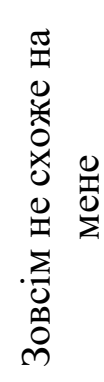 \\
\hline \multirow{10}{*}{5989} & $\begin{array}{l}\text { V70 Для цієї людини важливо пропонувати } \\
\text { нові ідеї, бути творчою особистістю, йти своїм } \\
\text { шляхом. }\end{array}$ & 9,5 & 20,0 & 23,5 & 19,8 & 20,6 & 6,6 \\
\hline & $\begin{array}{l}\text { V71 Для цієї людини важливо бути багатим, } \\
\text { мати багато грошей і коштовних речей. }\end{array}$ & 4,5 & 12,1 & 17,8 & 24,6 & 29,7 & 11,3 \\
\hline & $\begin{array}{l}\text { V72 Жити в безпеці дуже важливо для цієї } \\
\text { людини, він уникає усього, що може } \\
\text { передбачати небезпеку }\end{array}$ & 20,1 & 26,4 & 24,8 & 17,2 & 9,1 & 2,5 \\
\hline & $\begin{array}{l}\text { V73 Для цієї людини важливо добре проводити } \\
\text { час, балувати себе }\end{array}$ & 5,7 & 13,4 & 19,7 & 23,8 & 27,5 & 9,9 \\
\hline & $\begin{array}{l}\text { V74 Для цієї людини важливо робити щось } \\
\text { хороше для суспільства }\end{array}$ & 11,0 & 28,4 & 28,8 & 23,9 & 5,7 & 23,0 \\
\hline & $\begin{array}{l}\text { V75 Для цієї людини важливо бути дуже } \\
\text { успішним, щоб оточення знало про його } \\
\text { досягнення }\end{array}$ & 7,2 & 17,5 & 23,2 & 24,5 & 21,7 & 5,8 \\
\hline & $\begin{array}{l}\text { V76 Пригоди і ризик дуже важливі для цієї } \\
\text { людини, він прагне до життя, повного } \\
\text { захоплюючих подій }\end{array}$ & 4,3 & 9,4 & 16,6 & 18,9 & 32,8 & 18,0 \\
\hline & $\begin{array}{l}\text { V77 Для цієї людини важливо завжди } \\
\text { поводитися правильно, не здійснювати } \\
\text { вчинків, які люди не схвалили б }\end{array}$ & 18,6 & 28,5 & 26,2 & 15,3 & 9,3 & 2,1 \\
\hline & $\begin{array}{l}\text { V78 Для цієї людини важлива турбота про } \\
\text { довкілля і природу }\end{array}$ & 12,6 & 26,9 & 26,1 & 23,3 & 8,1 & 3,1 \\
\hline & $\begin{array}{l}\text { V79 Для цієї людини важливо наслідувати } \\
\text { традиції і звичаї, прийняті в його родині або } \\
\text { релігії }\end{array}$ & 24,6 & 32,4 & 22,2 & 12,8 & 5,8 & 2,1 \\
\hline
\end{tabular}


Складено автором на основі [проекту WVS]. За результатом опитування можна розглянути ієрархію потреб українців (див. рис. 2) на основі таблиці 1.

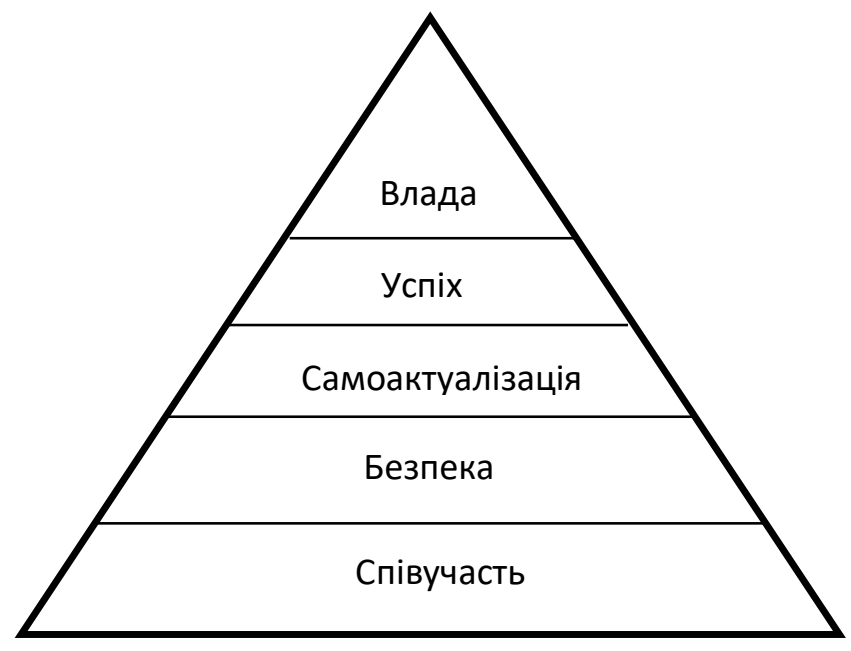

\section{Рис. 2. Ієрархія потреб українців}

Ієрархія потреб українців (рис. 1) складена автором на основі таблиці 1. Головним важелем мотивації для українців є співучасть. За Д. Мак-Клеландом [4, с. 125] потреба співучасті проявляється у вигляді прагнення до дружніх відносин 3 оточуючими. Люди 3 високою потребою співучасті намагаються встановлювати і підтримувати добрі стосунки, прагнуть отримати схвалення i підтримку з боку оточуючих, стурбовані тим, як про них думають інші.

Потребу в безпеці для робітників працюючих на підприємстві важливо відчувати, як і стабільність та знати, що в разі чого, організація допоможе у виникненні життєвих проблем.

Самоактуалізація для українців являє собою безперервну реалізацію потенційних можливостей, здібностей і талантів, як звершення своєї місії, або покликання. Важливо знати про таланти свого робітника, оскільки можна надати роботу пов'язану з захопленням і отримати більш високі результати.

Успіх можна розглянути як підвищення навичок та отримання більш високої посади. Для українців цей мотиватор є не досить важливим, але має місце бути. 
I останній за значенням для українців є важіль влади. Мотив, що спонукає людей докладати певних зусиль та долати значні труднощі в процесі діяльності - це і є прагнення керувати іншими людьми. Людина працює дуже багато заради того, щоб мати вплив на окрему людину та свій колектив 3 часом, а не заради саморозвитку та успіху компанії.

Висновки 3 проведеного дослідження. Методи мотивації є застарілими. Для рішення цієї проблеми можна ввести різноманітні методики для мотивації, провести певних заходів та запровадження нових важелів мотивації. Для українців головними важелями $є$ співучасть і безпека, тому важливо націлитися на мотиваційні заходи, які з цим пов'язані. При цьому не забувати і про базові потреби працівників. Було розроблена нова ієрархія потреб українців, на яку можна опиратися при підборі методів підвищення мотивації на підприємстві.

Це може призвести до того, щоб робота була бажаною, праця була як захоплення. Співробітники стали б здатні до цілеспрямованості i самоконтролю, змогли б самостійно визначати стратегії досягнення цілей. Вони будуть прагнути до саморозвитку. Працівники зможуть поєднувати роботу 3 відпочинком, що покращить внутрішній стан самого робітника і дасть змогу на креативність та самовіддачу.

\section{Перелік посилань}

1. Maslow Abraham. A Theory of Human Motivation. Psychological Review. 1943. № 50. P. 370-396.

2. Дмитриченко Л. И., Чунихина Т. С., Дмитриченко Л. А., Химченко А. Н. Корпорация в системе общественного производства: монография. Донецк, 2010. 220 с.

3. Наврузов Ю., Черепухіна Н. Мистецтво управління персоналом. Таланти і лідери. Київ, 2002. 300 с.

4. Mcclelland David C. Human Motivation. Clenview. : Scott, Foresman, 1985. p. 370. 
5. Онлайн аналіз проектом WVS : сайт. URL: http://www.worldvaluessurvey.org/WVSOnline.jsp (дата обращения : 4.01.2018).

6. Журавлев П.В., Карташов С.А. Технология управления персоналом. Москва, 2000. 575 с.

7. Мачтакова О. Г. Мотивація: від античності до постмодернізму : монографія. Одеса, 2013. 210 с.

8. Вилюнас Витис Казиса. Психологические механизмы биологической мотивации. Москва, 1986. 208 с.

9. Колот А. М., Цимбалюк С.О. Мотиваційний менеджмент: підручник. Київ, 2014. 479 с.

10. Фоксол Г., Голдстрит Р., Браун С. Психология потребителя в маркетинге. Санкт-Петербу́рг, 2001. 352 с.

\section{References}

1. Maslow, Abraham. A (1943), Theory of Human Motivation. Psychological Review. No. 50, P. 370-396.

2. Dmitrichenko L.I., Chunikhina T.S., Dmitrichenko L.A., Khimchenko A.N. (2010), Corporation in the system of social production [Korporatsiya $v$ sisteme obshchestvennogo proizvodstva], Donetsk, 220 p.

3. Navruzov Yu., Tcherupukhina N. (2002), Art of Personnel Management. Talents and Leaders [My`stecztvo upravlinnya personalom. Talanty` $i$ lidery'], Kiev, 300 p.

4. Mcclelland David C. (1985), Human Motivation, Clenview. : Scott, Foresman, $370 \mathrm{p}$.

5. Online project analysis WVS [Onlajn analiz proektom WVS], available at: http://www.worldvaluessurvey.org/WVSOnline.jsp (last accessed 4.01.2018)

6. Zhuravlev P.V., Kartashov S.A. (2000), Technology management personnel [Tekhnologiya upravleniya personalom], Moscow, $575 \mathrm{p}$.

7. Machtakova, O. G. (2013), Motivation: from antiquity to postmodernism [Moty`vaciya: vid anty chnosti do postmodernizmu], Odes, $210 \mathrm{p}$. 
8. Vilyunas Vitis Kazisa (1986), Psychological mechanisms of biological motivation [Psikhologicheskie mekhanizmy biologicheskoy motivatsii], Moscow, 208 p.

9. Kolot A. M., Tsimbalyuk S.O. (2014) Motivation Managemen [Motyvatsiinyi menedzhment], Kiev, 479 p.

10. Foksol, G., Goldstream R., Brown S., (2001), Consumer Psychology in marketing [Psikhologiya potrebitelya v marketinge], St. Petersburg, 352 p.

\section{Янченко Н. В., Благой В.В., Тихомирова А. О. МОТИВАЦІЯ ПЕРСОНАЛУ ЯК ВАЖІЛЬ ПІДВИЩЕННЯ ПРОДУКТИВНОСТІ ПРАЦІ НА ПІДПРИЕМСТВІ}

Mema: виявлення нових та вплив старих методів мотивації на персонал, удосконалення, яких може сприяти оптимізації виробництва на підприємстві. Методика дослідження: в роботі використано емпіричний та теоретичні методи дослідження. Результати: На сьогодні державні підприємства не приносять великого прибутку, однією з проблем є не досить гарна мотивація персоналу. Як результат більшість співробітників не любить роботу i намагається працювати заради грошей, співробітників необхідно змушувати виконувати роботу, використовуючи адміністративний, економічний i психологічний тиск. Це актуалізує необхідність дослідження проблем мотивації персоналу. Потребують подальшого розв'язання питання, пов'язані 3 оптимізацією виробництва, удосконаленням методів мотивації працівників та інше. Визначено, що для українців головними важелями є співучасть і безпека, тому важливо націлитися на мотиваційні заходи, які з цим пов'язані. Методи мотивації є застарілими. Для рішення цієї проблеми можна ввести різноманітні методики для мотивації, провести певних заходів та запровадження нових важелів мотивації. Для українців головними важелями є співучасть і безпека, тому важливо націлитися на мотиваційні заходи, які з цим пов'язані. При цьому не забувати і про базові потреби працівників. Було розроблена нова ієрархія потреб українців, на яку можна опиратися при підборі методів підвищення мотивації на підприємстві. Це може призвести до того, щоб робота була бажаною, праця була як захоплення. Співробітники стали б здатні до цілеспрямованості і самоконтролю, змогли б самостійно визначати стратегії досягнення цілей. Вони будуть прагнути до саморозвитку. Працівники зможуть поєднувати роботу з відпочинком, що покращить внутрішній стан самого робітника і дасть змогу на креативність та самовіддачу. Наукова новизна: Дістала подальшого розвитку ієрархія потреб українців, на яку можна опиратися при підборі методів мотивації на підприємстві для оптимізації продуктивності праці. Практична значущість: результати дослідження можна впровадити на підприємствах i організаціях для підвищення продуктивності праці. 
Ключові слова: робітничі кадри; персонал підприємства; мотивація; важелі мотивації; продуктивність праці.

\section{Янченко Н. В., Благой В.В., Тихомирова А. О. МОТИВАЦИЯ ПЕРСОНАЛА КАК РЫЧАГ ПОВЫШЕНИЯ ПРОИЗВОДИТЕЛЬНОСТИ ТРУДА}

Цель: выявление новых и влияние старых методов мотивации на персонал, усовершенствования, которые могут способствовать оптимизации производства на предприятии. Методика исследования: в работе использованы эмпирический и теоретические методы исследования. Pезультаты: На сегодня государственные предприятия не приносят большой прибыли, одной из проблем является недостаточно хорошая мотивация персонала. В результате большинство сотрудников не любит работу и пытается работать ради денег, сотрудников необходимо заставлять выполнять работу, используя административное, экономическое и психологическое давление. Это актуализирует необходимость исследования проблем мотивации персонала. Требуют дальнейшего решения вопросы, связанные с оптимизацией производства, совершенствованием методов мотивации работников и прочее. Определено, что для украинцев главными рычагами является соучастие и безопасность, поэтому важно нацелиться на мотивационные мероприятия, которые с этим связаны. Методы мотивации являются устаревшими. Для решения этой проблемы можно ввести различные методики для мотивации, провести определенные меры и внедрение новых рычагов мотивации. Для украинцев главными рычагами является соучастие и безопасность, поэтому важно нацелиться на мотивационные мероприятия, которые с этим связаны. При этом не забывать и о базовых потребностях работников. Было разработана новая иерархия потребностей украинцев, на которую можно опираться при подборе методов повышения мотивации на предприятии. Это может привести к тому, чтобы работа была желанной, работа была в удовольствие. Сотрудники стали бы способны к целеустремленности и самоконтролю, смогли бы самостоятельно определять стратегии достижения целей. Они будут стремиться к саморазвитию. Работники смогут совмещать работу с отдыхом, что улучшит внутреннее состояние самого работника и повлияет на креативность и самоотдачу. Научная новизна: Получила дальнейшее развитие иерархия потребностей украинцев, на которую можно опираться при подборе методов мотивации на предприятии для оптимизации производительности труда. Практическая значимость: результаты исследования можно внедрить на предприятиях и организациях для повышения производительности труда.

Ключевые слова: рабочие кадры; персонал предприятия; мотивация; рычаги мотивации; производительность труда.

Yanchenko N. V., Blagoy V., Tikhomyrova A. A. THE MOTIVATION OF STAFF AS A LEVER TO INCREASE PRODUCTIVITY IN THE ENTERPRISE 
Purpose: to identify new and influence the old methods of motivation on staff, improvements that can help optimize production at the enterprise. Methodology of research: empirical and theoretical methods of research are used in the work. Findings: Today, state-owned enterprises do not bring great profits, one of the problems is the lack of good motivation of the staff. As a result, most employees do not like work and try to work for the sake of money, employees must be forced to perform work, using administrative, economic and psychological pressure. This updates the need for research on motivation issues for staff. The issues related to optimization of production, improvement of methods of motivation of employees and others are required for further resolution. It has been determined that for Ukrainians, the main levers are co-participation and security, so it is important to focus on the motivational activities that are associated with it. Methods of motivation are obsolete. To solve this problem, you can introduce various methods for motivation, take certain measures and introduce new motivational levers. For Ukrainians, the main levers are complicity and security, so it's important to focus on the motivational activities that are associated with it. At the same time, do not forget about the basic needs of workers. A new hierarchy of needs of Ukrainians was developed, on which one can rely on selecting methods for enhancing motivation at the enterprise. This can lead to the work being desired, work was pleasure. Employees would be capable of purposefulness and self-control, would be able to independently determine strategies for achieving goals. They will strive for self-development. Workers will be able to combine work with rest, which will improve the internal state of the employee and will affect creativity and self-efficacy. Originality: Get further development hierarchy of needs of Ukrainians has been developed, which can be based on the selection of motivation methods at the enterprise to optimize labor productivity. Practical significance: the results of the research can be implemented at enterprises and organizations to increase labor productivity.

Key words: workforce; the staff of the enterprise; motivation; the levers of motivation; productivity.

\section{Відомості про авторів:}

Янченко Наталія Вікторівна - кандидат економічних наук, доцент, Харківський національний університет будівництва та архітектури, доцент кафедри економіки, м. Харків, Україна; e-mail:yanchenko300076@gmail.com; ORCID ID: https://orcid.org/0000-0001-8447-5123. моб. +380979495592.

Янченко Наталья Викторовна - кандидат экономических наук, доцент, Харьковский национальный университет строительства и архитектуры, доцент кафедры экономики, г.. Харьков, Украина.

Yanchenko Nataliya Viktorovna - candidate of economic sciences, Associate Professor, Kharkov National University of construction and architecture, Associate Professor of Economics, c. Kharkiv, Ukraine.

Благой Віталій Валерійович - кандидат економічних наук, доцент, Харківський національний університет будівництва та архітектури, доцент 
кафедри економіки, м. Харків, Україна; e-mail: blagoyvitval@i.ua; ORCID ID: https://orcid.org/0000-0002-0702-561Х. Моб. 050-512-60-50.

Благой Виталий Валерьевич - кандидат экономических наук, доцент, Харьковский национальный университет строительства и архитектуры, доцент кафедры экономики, г. Харьков, Украина.

Blagoy Vitaly - Candidate of Sciences (Economics), Associate Professor, Kharkov National University of Construction and Architecture, Associate Professor at the Department of Economics, Kharkiv, Ukraine.

Тихомирова Анастасія Олексіївна - ст. групи ЕП-41 спеціальності «Економіка підприємства», Харківський національний університет будівництва та архітектури, м. Харків, Україна; e-mail: inastia2618@gmail.com; моб. +380669857453 .

Тихомирова Анастасия Алексеевна - ст. группы ЭП-41 специальности «Экономика предприятия», Харьковский национальный университет строительства и архитектуры,. Харьков, Украина.

Tikhomyrova Anastasiya Alekseevna - student of the group of EP-41 specialty "Enterprise Economics", Kharkiv National University of Construction and Architecture, Kharkiv, Ukraine. 